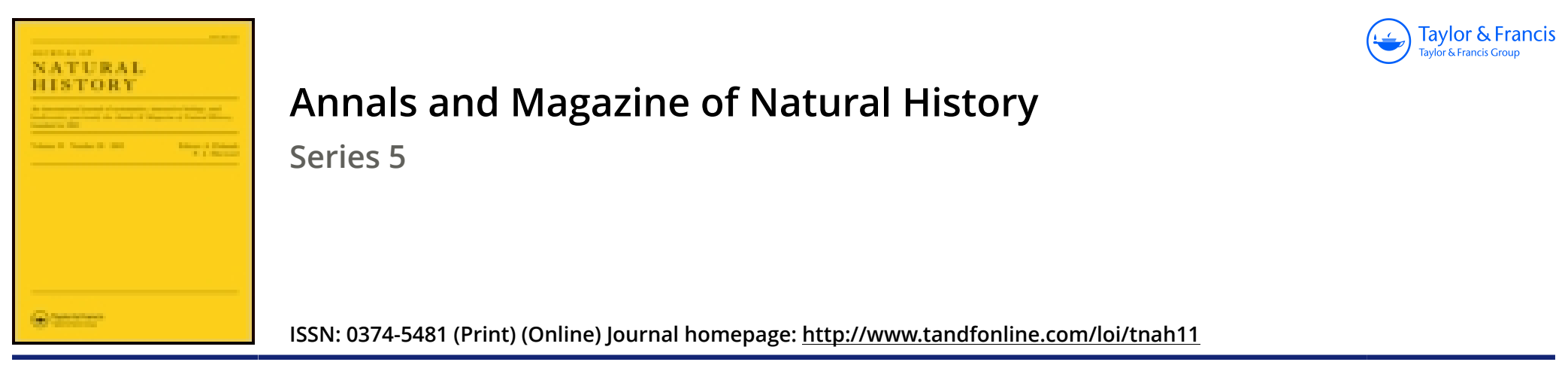

\title{
XXIV.-Notes on some species of Inland mollusca
}

\section{T.D.A. Cockerell}

To cite this article: T.D.A. Cockerell (1887) XXIV.-Notes on some species of Inland mollusca, Annals and Magazine of Natural History, 19:111, 174-176, DOI: 10.1080/00222938709460225

To link to this article: http://dx.doi.org/10.1080/00222938709460225

$$
\text { 曲 Published online: } 12 \text { Oct } 2009 .
$$

Submit your article to this journal ๔

Џll Article views: 1

Q View related articles $\asymp$ 
T. wheurus, nens. The following synopsis is made from the specimens transmitted by the above-named gentleman :-

I. Lateral line continued to the tail.

A. Dorsal with nine branched rays.

Depth of the body not more than twice and a half in the total length (without caudal); 22 to 28 branched rays in the anal; scales $\frac{\frac{7}{34-37}}{6} \ldots \ldots \ldots \ldots \ldots \ldots \ldots \ldots \ldots$ maculatus.

Depth of the body more than twice and a haif in the total length ; diameter of the eye much greater than the length of the snout; 19 to 24 branched rays in the anal; scales $\frac{\frac{\pi-8}{36-39}}{5} \ldots \ldots \ldots \ldots \ldots \ldots \ldots \ldots \ldots \ldots$ nutilus.

Depth of the body thrice in the total length; diameter of the eye not exceeding the length of the snout; 19 branched rays in the anal $;$ scales $\frac{7}{4} \ldots \ldots \ldots \ldots \ldots \ldots \ldots$ obscturts.

3. Dorsal with eight branched rays; and with sixteen to eighiteen.

Depth of the body more than twice and a half in the total length (without caudal); scales $\frac{\frac{5-5 \frac{1}{2}}{35}-37}{3-4} \ldots \ldots \ldots \ldots$ lheringii.

II. Lateral line not continued to the tail.

Dereal with rine branched rays; anal with twenty-one or twenty-two: depth of the body not more than twice and $n$ haif in the total length (without caudal); scales 5

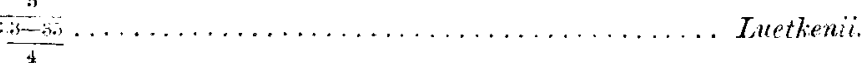

\section{XXIV.-Nofes on some Species of Inland Mullusca. By '.' D. A. Cockerell.}

\section{Arion ater, L.}

The distribution of the colour-varietics of this species is peculiar: a bright brick-red form (var. mubra, Moq.-l'and. 1855) appears to be prevalent in Belgium, though, so far as is at present known, it does not occur in Britain. My brother found it commonly at Brussels, and last year the Hon. Miss M. C. E. Leigh sent me specimens from Spa, together with the variety Draparnaldi, Moq., and Arion subfuscus, Drap. It is generally supposed that the red forms of Arion are developed in dry situations, while the darker or black varieties inhabit damp and marky spots; and this seems to have been 
the case with the Belgian var. rubra, as Miss Leigh writes:"I observed three red slugs, two in one path and one in another, in a wood outside and some way above the town. The paths were a short distance from a stream, but themselves very dry, full of stones and slate, surrounded by grass, heather, and bushes." My brother (S. C. C.) has also taken the brick-red variety at Rouen.

\section{Succinea vitrea, Jeffr.}

'This species was first described as S. putris, var. vitrea * by Gwyn Jeffreys, who subsequently identified it with Morelet's S. virescens $t$, and it has since been known under the latter name to British conchologists. As a species I think it is at least as distinct as most others of the genus; but it seems extremely doubtful whether our form is Morelet's $S$. virescens, since the figure of that species given by Kobelt (Rossm. Icon. fig. 2088) belongs evidently to a variety or subspecies of S. Pfeifferi. Baudon's S. debilis closely resembles our species in shape, but it is much smaller, and appears also to belong to the Pfeifferi-section of the genus. It therefore becomes necessary, since neither Morelet's virescens nor Baudon's debilis belong even to the same section of the genus, to adopt for our species Jeffreys's name vitrea $\ddagger$, the characters being a short and blunt spire, shallow suture, large aperture, and the ex-
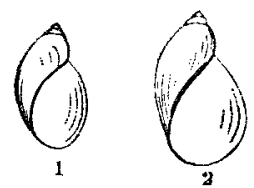

Succinea vitrea, Jeffreys.

1. Wressle, Yorks. 2. Var. aurea: Clonmel.

tremely fragile and thin texture of the shell. The typical form of the species is pale greenish and transparent, sometimes inclining to pale brown; but a variety which I call aurea occurs near Clonmel in Ireland, and is of a beautiful translucent amber colour.

* 'British Conchology' vol. i. p. 152.

$\dagger$ Ann. \& Mag. Nat. Hist. Nov. 1878.

I $S$. vitrea has been recorded from the following counties in Britain :Kent, Surrey, Middlesex, Warwick, Herts, Hants, Worcester, Sussex, Carmarthen, Tipperary, and Cork; and I have recently received it from Yorkshire, which is the most northern locality at present known. 


\section{Succinea Pfeifferi, Rossm. (S. ovalis, Gould).}

This has been very generally known as $S$. elegans in England, but the true $\dot{S}$. elegans, Risso, is comparatively scarce in this country.

Gould's Succinea ovalis, which is very common on the North-American continent, is undoubtedly identical with this species, and indeed it would seem that S. Pfeifferi or ovalis had its origin, together with such species as Helix pulchella and Cochlicopa lubrica, in the boreal regions of Europe and America, at a time when the two continents were still Succinea ovalis, Gould. united. S. elegans, on the other hand, St. Thomas, Ontario. seems to have its greatest development in central and southern Europe, producing such forms as $S$. Dunkeri, Zeleb., S. hungarica, Hazay, and S. megalonyxia, Bourg. In an interesting collection of shells from St. Thomas, Ontario, Canada, sent to me by my brother (Mr. D. B. Cockerell), there are specimens of $s$. ovalis, which are searcely to be distinguished from Baudon's var. ventricosa of S. Pfeifferi, and from the same locality such well-known European forms as Conulus fulvus, Drap., Helix pulchella, Müll. (type form), Cochlicopa lubrica, Miill., Limncea truncatula, Minll. (of the American form humilis, Say, and an elongated variety resembling rustica, Lea), Planorbis parvus, Say (=glaber, Jeffreys), and Pisidium pusillum, Gmel. (=abdilum, Hald.), as well as an abundance of Ameriean species, sone very closely allied to European forms, and others peculiarly American, the list including:-Hyalina indentata, Say; $H$. electrina, Gould; $H$. arborea, Say ; H. minuscula, Binney; Helicodiscus lineatus, Say; Conulus chersinus, Say (var.); Helix alternata, Say; H. perspectiva, Say (var.); H. striatella, Anth.; H. monodon, Rack, and a distinct variety; $H$. albolabris, Say; Pupa contracta, Say; P. rupicola, Say; P. fallax, Say; Planorbis armigenus, Say; Pomatiopsis lapidaria, Say; Pisidium variabile, Prime; Sphorium striatinum, Lam.; $S$. tumidum, Prime; and S. sulcatum, Lam.

5 Priory Road, Bedfi rd Park,

Chiswick, Feb. 6, 1887. 